\title{
Stud-breeding work in sheep breeding based on cytogenetic monitoring
}

\author{
Vladimir Ivanovich Rossokha ${ }^{1,}$, , Ivan Andreevich Pomitun ${ }^{1}$, Alexandr Vladimirovich \\ Tkachev $^{2,3}$, Olga Leonidovna Tkacheva ${ }^{2}$, Tatyana Vladimir Zubova ${ }^{4}$, Vladimir \\ Aleksandrovich Pleshkov ${ }^{4}$, and Oksana Vladimirovna Smolovskaya ${ }^{4}$ \\ ${ }^{1}$ National Academy of Agrarian Sciences of Ukraine, st. Livestock breeders, 1A, 61026 Kharkov, \\ Ukraine \\ ${ }^{2}$ Belgorod State Agrarian University, 308503, st. Vavilova, 1, vil. Maysky, Belgorodsky, Belgorod, \\ Russia \\ ${ }^{3}$ Federal State Budgetary Educational Institution of Higher Education Penza State Agrarian \\ University, 440014, st. Botanicheskaya, 30, Penza, Russia \\ ${ }^{4}$ Kuzbass State Agricultural Academy, 650056, st. Markovtseva, 5, Kemerovo, Russia
}

\begin{abstract}
The article presents the results of the cytogenetic monitoring in the breeding, selection and reproduction of sheep in the ecological conditions of Ukraine. A cytogenetic analysis of sheep with low and high vigor and different levels of fertility was carried out. In the ecological conditions of Ukraine, the individual level of chromosomal abnormalities in all the studied animals of the Tsigai breed and prekos is within the natural background. No translocations were found. Among the violations, such as single and paired fragments, hypo- and hyperploidy (mainly hypoploidy), polyploidy were encountered. The maximum average level of chromosomal abnormalities was found in local lambs $(5.5 \pm 1.73 \%)$. The minimum average level of chromosomal abnormalities $(2.0 \pm 1.41 \%)$ was recorded in lambs with high growth intensity. Among the structural changes, mutations of the chromosomal type prevailed in the 3 -year-old group of rams $-0.46 \%$, in the 8 -year-old group - $0.59 \%$. Chromatid disturbances were $0.37 \%$ and $0.34 \%$, respectively. The average level of chromosomal abnormalities in rams by groups was $0.84 \pm 0.14$ and 0.93 \pm 0.13 , respectively. In the group of ewes with low fertility $(n=4)$, the level of chromosomal abnormalities was $3.5 \%$, which is lower than ewes $(\mathrm{n}=7)$ with high fertility by $0.79 \%$.
\end{abstract}

\section{Introduction}

At the beginning of the XXI century, in the context of the European integration policy, on the agenda of livestock breeders was the question of harmonizing primary accounting in animal husbandry with the requirements of the International Committee for Animal Recording (ICAR), the mandatory requirement of which is the detection of carriers hereditary developmental anomalies based on genetic examination. In Ukraine, in 2004, the "Regulation on the procedure for carrying out genetic examination of the origin and

${ }^{\star}$ Corresponding author: rossokha.v@ukr.net 
anomalies of pedigree animals" was developed and introduced into practice, which regulates the genetic examination of the origin of pedigree animals, the identification of genetic and chromosomal anomalies [1-4].

\section{Literature Review}

In developed countries of the world, cytogenetic monitoring programs in breeding farms began to be applied without fail since the 70s of the last century. In Ukraine, cytogenetic studies of sheep were actively carried out in the 80 s of the last century, which remained in the history of genetics as a cytogenetic boom. Most of the breeds of sheep and cattle were examined, the frequency and spectrum of chromosomal aberrations in blood cells were found, a number of carriers of chromosomal abnormalities characteristic of sheep were identified, which caused a decrease in vitality and reproductive function. In the scientific literature, many publications have appeared on the identification of various chromosomal aberrations and their influence on the phenotypic characteristics of animals of different species and breeds [5-9].

Based on the foregoing, cytogenetic monitoring is of great scientific and practical importance in all branches of animal husbandry (sheep breeding, horse breeding, cattle breeding, pig breeding) in order to eliminate animal carriers of chromosomal aberrations, in order to increase reproductive function, increase the efficiency of creating cryobanks of valuable producers [7-11]. Since modern methods of animal reproduction - artificial insemination, embryo transplantation, etc. lead to the risk of the spread of hereditary cytogenetic abnormalities. It has been established that various anomalies of the karyotype are often found in cattle and can have a significant effect on their vital activity, reproductive function and productivity. An economic analysis of the consequences of the use of carriers of hereditary chromosomal aberrations in the breeding process showed an impressive amount of losses for the livestock industry on farms [13-14].

\section{Materials and methods}

Cytogenetic monitoring was carried out in sheep-breeding farms of Ukraine in 2019-2020 at LLC "Kiseli", SPD "Tretyakova O.A." (Romanov breed), DPDG "Gontarovka" and CJSC AF "March 8" (prekos), "Volodarskoe" and LLC AF "Agrotis" (Askanian meat and wool), AF "Liya" and breeding plant LLC "Donagrolux" (Tsigai breed Azov type), LLC AF "Dobrobut" (Sokolskaya), SE AF "Shakhtar" (Merino Askanian Tavrichesky type).

Sheep chromosome preparations were prepared according to generally accepted methods [10-12] in a sterile box. The production of a culture of sheep peripheral blood lymphocytes included a number of stages: the cultivation of peripheral blood lymphocytes stimulated by phytohemaglutinin (PHA) (Sigma, USA) in a mixture of Igla nutrient medium for 48 hours in a thermostat at $37^{\circ} \mathrm{C}$. Stopping mitosis was carried out 2 hours before the end of cultivation by adding colchicine at a concentration of $1 \mathrm{mg} / \mathrm{ml}$. In sterile vials with blood samples ( $1 \mathrm{ml}$, about 5000 lymphocytes), $5-8 \mathrm{ml}$ of culture medium 199 or Eagle was added, added to $2 \mathrm{ml}$ of IST (inactivated calf serum) and PHA (6-12 $\mu \mathrm{g} / \mathrm{ml}$ of the final volume of the culture medium), penicillin or streptomycin $100 \mathrm{mg} / \mathrm{ml}$. The resulting suspension was thoroughly mixed and placed in a thermostat for cultivation for 48 hours at a temperature of $37^{\circ}$ C. 30 minutes before the end of cultivation, colchicine was injected into each sample in an amount of $1 \mathrm{mg}$ per $1 \mathrm{ml}$ of medium. After the completion of the cultivation, centrifugation was carried out for 10 minutes at $1000 \mathrm{rpm}$. After centrifugation, the supernatant was aspirated and a hypotonic solution of $0.5 \% \mathrm{KCl}$ warmed to $37^{\circ} \mathrm{C}$ was added. Then 3-4 drops of the cell suspension were dropped onto the glass 
slide from a height of $10-15 \mathrm{~cm}$ and dried. After hypotonic treatment with $0.5 \% \mathrm{KCl}$ for 20 minutes, the cells were fixed with a mixture of ethanol and glacial acetic acid. The cell suspension was applied to wet cooled glass slides and dried. Analysis of chromosome preparations was carried out on preparations stained with Giemsa dye using a Jenaval microscope (Carl Zeiss, Germany) with oil immersion at a magnification of 1000 times. At the same time, the total chromosomal instability was taken into account as a percentage (percentage of metaphases with aberrations) in the structure of aberrations, single aberrations, paired aberrations, circular chromosomes or acentric rings, gaps and breaks of chromosomes, and others were taken into account [10-12].

Statistical processing of the data was carried out using generally accepted methods of variation statistics; the reliability of differences was assessed by the Student's t-test using a specialized software package SPSS for Windows ("IBM", USA). The tables show mean (M) and mean deviations ( $\pm \mathrm{m})$.

\section{Results and Discussions}

According to the results of the conducted studies of the sheep of the Tsigai breed of the Azov meat-wool type in the peripheral blood (Table 1-2), no characteristic anomalies were revealed for all aberrant cells. The structural variability of chromosomes was established, which was at the level of $0.89 \pm 0.18$.

Table 1. Structural mutations in peripheral blood cells of rams of different ages $(M \pm m ; n=991)$

\begin{tabular}{|c|c|c|c|c|}
\hline $\begin{array}{c}\text { Age group } \\
\text { (years) }\end{array}$ & $\begin{array}{c}\text { Number of } \\
\text { metaphases }\end{array}$ & Chromosomal & Chromatid & $\begin{array}{c}\text { Average level of } \\
\text { aberrations, \% }\end{array}$ \\
\hline up to 3 & 511 & 0,46 & 0,37 & $0,84 \pm 0,14$ \\
\hline up to 8 & 480 & 0,59 & 0,34 & $0,93 \pm 0,13$ \\
\hline
\end{tabular}

Among the structural changes, mutations of the chromosomal type prevailed in the 3year-old group of rams $-0.46 \%$, in the 8 -year-old group $-0.59 \%$. Chromatid abnormalities were $0.37 \%$ and $0.34 \%$, respectively. The average level of chromosomal abnormalities in rams by groups was $0.84 \pm 0.14$ and $0.93 \pm 0.13$, respectively.

Polyploidy was predominantly tetraploid and no significant difference was found between the two age groups.

Table 2. Genomic mutations in peripheral blood cells of stud rams of different ages $(M \pm m ; n=991)$

\begin{tabular}{|c|c|c|c|}
\hline $\begin{array}{c}\text { Age group } \\
\text { (years) }\end{array}$ & $\begin{array}{c}\text { Number of } \\
\text { metaphases }\end{array}$ & Aneuploidy, \% & Polyploidy, \% \\
\hline up to 3 & 511 & $13,14 \pm 0,46$ & $1,23 \pm 0,07$ \\
\hline up to 8 & 480 & $20,40 \pm 0,9$ & $1,38 \pm 0,13$ \\
\hline
\end{tabular}

A cytogenetic analysis of sheep with low and high vigor and different levels of fertility was carried out. The individual level of chromosomal abnormalities in all studied animals is within the natural norm. No translocations were found. Among the violations, there were such as single and paired fragments, hypo- and hyperploidy (mainly hypoploidy), polyploidy. The maximum average level of chromosomal abnormalities was determined in lambs of German origin $(5.5 \pm 1.73 \%)$. The minimum average level of chromosomal abnormalities $(2.0 \pm 1.41 \%)$ was recorded in lambs with a high growth rate. In animals with low growth intensity $(\mathrm{n}=5)$, the average level of chromosomal abnormalities was $3.60 \pm$ $2.05 \%$ (group 1) (Table 3). 
Table 3. Chromosome profile of lambs with different growth rates

\begin{tabular}{|c|c|c|c|c|c|c|c|}
\hline $\begin{array}{l}\text { № of } \\
\text { heads }\end{array}$ & $\begin{array}{c}\text { Aneuploidy, } \\
\%\end{array}$ & $\begin{array}{c}\text { Polyploidy, } \\
\%\end{array}$ & $\begin{array}{c}\text { Single } \\
\text { fragments, } \%\end{array}$ & $\begin{array}{c}\text { Paired } \\
\text { fragments, } \%\end{array}$ & 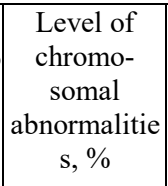 & 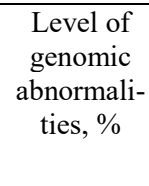 & $\begin{array}{c}\text { Level of } \\
\text { structural } \\
\text { abnormali- } \\
\text { ties, \% }\end{array}$ \\
\hline \multicolumn{8}{|c|}{ lambs with low growth rate (first group) } \\
\hline 201 & 4 & 2 & 4 & 0 & 10 & 6 & 4 \\
\hline 344 & 0 & 0 & 0 & 0 & 0 & 0 & 0 \\
\hline 334 & 0 & 0 & 0 & 0 & 0 & 0 & 0 \\
\hline 347 & 0 & 4 & 0 & 0 & 4 & 4 & 0 \\
\hline 248 & 0 & 2 & 2 & 0 & 4 & 2 & 2 \\
\hline $\mathrm{M} \pm \mathrm{m}$ & $0,8 \pm 0,89$ & $1,6 \pm 0,84$ & $1,2 \pm 0,89$ & 0 & $3,6 \pm 2,05$ & $2,4 \pm 1,30$ & $1,2 \pm 0,89$ \\
\hline \multicolumn{8}{|c|}{ lambs with high growth rate (second group) } \\
\hline 14 & 2 & 0 & 0 & 0 & 2 & 2 & 0 \\
\hline 28 & 2 & 2 & 0 & 0 & 4 & 4 & 0 \\
\hline 493 & 0 & 0 & 0 & 0 & 0 & 0 & 0 \\
\hline $\mathrm{M} \pm \mathrm{m}$ & $1,33 \pm 0,82$ & $0,67 \pm 0,82$ & 0 & 0 & $2,0 \pm 1,41$ & $2,0 \pm 1,41$ & 0 \\
\hline \multicolumn{8}{|c|}{ local lambs (third group) } \\
\hline 477 & 2 & 2 & 0 & 0 & 4 & 4 & 0 \\
\hline 476 & 2 & 0 & 2 & 0 & 4 & 2 & 2 \\
\hline 423 & 2 & 2 & 0 & 0 & 4 & 4 & 0 \\
\hline 437 & 0 & 6 & 2 & 2 & 10 & 6 & 4 \\
\hline $\mathrm{M} \pm \mathrm{m}$ & $1,5 \pm 0,58$ & $2,5 \pm 1,45$ & $1,0 \pm 0,67$ & $0,5 \pm 0,58$ & $5,5 \pm 1,73$ & $4,0 \pm 0,94$ & $1,5 \pm 1,11$ \\
\hline
\end{tabular}

In the group of animals ( $\mathrm{n}=3$ ) with high growth intensity (second group), the average level of chromosomal abnormalities was $2.0 \pm 1.41 \%$. Structural disorders $(1.20 \pm 0.89 \%)$ were present only in the first group of lambs. In the second group (with high growth intensity), only genomic abnormalities of $2.0 \pm 1.41 \%$ were recorded. In lambs of German selection $(n=4)$, the average level of chromosomal abnormalities was $5.5 \pm 0.73 \%$, where genomic abnormalities accounted for $4.0 \pm 0.94 \%$, and structural abnormalities accounted for $5 \pm 1.11 \%$, in this group of animals, the percentage of violations was higher in all parameters than in the previous two groups.

In the group of ewes $(n=11)$, the average level of chromosomal abnormalities is $4.0 \pm$ $0.89 \%$, which corresponds to the natural background. Among structural disorders $(0.36 \pm 0.26 \%)$, both paired and single fragments were encountered with the same frequency. Among genomic disorders $(3.27 \pm 0.71 \%$ ), aneuploidy prevailed, mainly hypoploidy (Table $4)$. 
Table 4. Chromosomal profile of ewes

\begin{tabular}{|c|c|c|c|c|c|c|c|}
\hline $\begin{array}{c}\text { № } \\
\text { of heads }\end{array}$ & $\begin{array}{c}\text { Aneuploidy, } \\
\%\end{array}$ & $\begin{array}{c}\text { Polyploidy, } \\
\%\end{array}$ & $\begin{array}{c}\text { Single } \\
\text { fragments, } \\
\%\end{array}$ & $\begin{array}{c}\text { Paired } \\
\text { fragments, } \\
\%\end{array}$ & $\begin{array}{c}\text { Level of } \\
\text { chromoso- } \\
\text { mal } \\
\text { abnormali- } \\
\text { ties, } \%\end{array}$ & $\begin{array}{c}\text { Level of } \\
\text { genomic } \\
\text { abnormali- } \\
\text { ties, } \%\end{array}$ & $\begin{array}{c}\text { Level of } \\
\text { structural } \\
\text { abnormali- } \\
\text { ties, } \%\end{array}$ \\
\hline 3584 & 0 & 0 & 0 & 0 & 0 & 0 & 0 \\
\hline 4722 & 4 & 0 & 0 & 0 & 4 & 4 & 0 \\
\hline 4661 & 0 & 0 & 0 & 0 & 0 & 0 & 0 \\
\hline 2630 & 4 & 0 & 0 & 0 & 4 & 4 & 0 \\
\hline 4572 & 2 & 0 & 0 & 2 & 4 & 2 & 2 \\
\hline 3529 & 6 & 0 & 2 & 0 & 8 & 6 & 2 \\
\hline 4657 & 4 & 2 & 2 & 0 & 8 & 6 & 2 \\
\hline 3500 & 2 & 2 & 0 & 2 & 6 & 4 & 2 \\
\hline 3489 & 2 & 4 & 0 & 0 & 6 & 6 & 0 \\
\hline 3490 & 2 & 0 & 0 & 0 & 2 & 2 & 0 \\
\hline 2582 & 2 & 0 & 0 & 0 & 2 & 2 & 0 \\
\hline $\mathrm{M} \pm \mathrm{m}$ & $2,55 \pm 0,57$ & $0,73 \pm 0,43$ & $0,36 \pm 0,26$ & $0,36 \pm 0,26$ & $4,0 \pm 0,89$ & $3,27 \pm 0,71$ & $0,73 \pm 0,32$ \\
\hline
\end{tabular}

In the group of ewes with low fertility $(n=4)$, the level of chromosomal abnormalities was $3.5 \%$, which is lower than ewes $(\mathrm{n}=7)$ with high fertility by $0.79 \%$. Among the chromosomal abnormalities, genomic ones prevailed (Table 5).

Table 5. Chromosomal profile of ewes with different fertility

\begin{tabular}{|c|c|c|c|c|c|c|c|}
\hline $\begin{array}{c}\text { № } \\
\text { of heads }\end{array}$ & $\begin{array}{c}\text { Aneuploidy, } \\
\%\end{array}$ & $\begin{array}{c}\text { Polyploidy, } \\
\%\end{array}$ & $\begin{array}{c}\text { Single } \\
\text { fragments, } \\
\%\end{array}$ & $\begin{array}{c}\text { Paired } \\
\text { fragments, } \\
\%\end{array}$ & \begin{tabular}{|c|} 
Level of \\
chromosomal \\
abnormalities, \\
$\%$
\end{tabular} & $\begin{array}{c}\text { Level of } \\
\text { genomic } \\
\text { abnormalities } \\
\%\end{array}$ & $\begin{array}{c}\text { Level of } \\
\text { structural } \\
\text { abnormalities, } \\
\%\end{array}$ \\
\hline \multicolumn{8}{|c|}{ ewes with low fertility } \\
\hline 3584 & 0 & 0 & 0 & 0 & 0 & 0 & 0 \\
\hline 4722 & 4 & 0 & 0 & 0 & 4 & 4 & 0 \\
\hline 3529 & 6 & 0 & 2 & 0 & 8 & 6 & 2 \\
\hline 3490 & 2 & 0 & 0 & 0 & 2 & 2 & 0 \\
\hline $\mathrm{M} \pm \mathrm{m}$ & $3,0 \pm 1,49$ & 0 & $0,5 \pm 0,58$ & 0 & $3,5 \pm 1,97$ & $3,0 \pm 1,49$ & $0,5 \pm 0,58$ \\
\hline \multicolumn{8}{|c|}{ ewes with high fertility } \\
\hline 4661 & 0 & 0 & 0 & 0 & 0 & 0 & 0 \\
\hline 2630 & 4 & 0 & 0 & 0 & 4 & 4 & 0 \\
\hline 4572 & 2 & 0 & 0 & 2 & 4 & 2 & 2 \\
\hline 4657 & 4 & 2 & 2 & 0 & 8 & 6 & 2 \\
\hline 3500 & 2 & 2 & 0 & 2 & 6 & 4 & 2 \\
\hline 3489 & 2 & 4 & 0 & 0 & 6 & 6 & 0 \\
\hline 2582 & 2 & 0 & 0 & 0 & 2 & 2 & 0 \\
\hline $\mathrm{M} \pm \mathrm{m}$ & $2,29 \pm 0,56$ & $1,4 \pm 0,64$ & $0,29 \pm 0,31$ & $0,57 \pm 0,39$ & $4,29 \pm 0,53$ & $3,43 \pm 0,91$ & $0,86 \pm 0,44$ \\
\hline
\end{tabular}


From the data in Table 5, it can be seen that in the environmental conditions of Ukraine, chromosomal instability increases in queens with low fertility.

\section{Conclusions}

It was revealed that in the ecological conditions of the south of Ukraine, the individual level of chromosomal abnormalities in all studied animals of the Tsigai breed and the prekos is within the natural background. No translocations were found. Among the violations, there were such as single and paired fragments, hypo- and hyperploidy (mainly hypoploidy), polyploidy. The maximum average level of chromosomal abnormalities was found in local lambs $(5.5 \pm 1.73 \%)$. The minimum average level of chromosomal abnormalities $(2.0 \pm 1.41 \%)$ was recorded in lambs with high growth rates. Among the structural changes, mutations of the chromosomal type prevailed in the 3-year-old group of rams $-0.46 \%$, in the 8 -year-old group - $0.59 \%$. Chromatid abnormalities were $0.37 \%$ and $0.34 \%$, respectively. The average level of chromosomal abnormalities in rams by groups was $0.84 \pm 0.14$ and $0.93 \pm 0.13$, respectively. In the group of ewes with low fertility $(n=4)$, the level of chromosomal abnormalities was $3.5 \%$, which is lower than ewes $(n=7)$ with high fertility by $0.79 \%$.

\section{References}

1. V.V. Aboneev, Collection of scientific papers of the Stavropol Scientific Research Institute of Livestock and Forage Production, 1-1, 12(2003)

2. V.I. Glazko, Agricultural biology, 4, 659 (2018)

3. A.V. Deikin, M.I. Selionova, A. Yu. Krivoruchko, D.V. Kovalenko, V.I. Trukhachev, Vavilov Journal of Genetics and Breeding, 5, 576(2016)

4. T.E. Deniskova, A.V. Dotsev, E.A. Gladyr, A.A. Sermyagin, V.A. Bagirov, U. V. Khompodoeva, A.N. Ilyin, G. Brem, N.A. Zinovieva, Agricultural biology, 6, 746 (2015)

5. L.G. Moiseykina, M. Rozikova, N.S. Marzanov, In the collection: Materials of the international scientific-practical conference on sheep and goat breeding, dedicated to the 65th anniversary of VNIIOK, 91(1997)

6. L.G. Moiseikina, N.S. Marzanov, In the collection: Topical issues of agricultural production in the Republic of Kalmykia Kalmyk Research Institute of Agriculture. Elista, 40(1997)

7. Yu.A. Stolpovsky, I.A. Zakharov-Gesekhus, Vavilov Journal of Genetics and Breeding, 4, 477(2017)

8. A.V. Tkachev, V.I. Sheremet, O. L. Tkacheva, Scientific Bulletin of Lviv National University of Veterinary Medicine and Biotechnology imene S.Z. Izhitsky, 2-2(67), 241(2016)

9. A.V. Tkachev, A.A. Evsyukova, A.D. Frundina, Innovative solutions in agricultural science - a look into the future Proceedings of the XXIII international scientific and industrial conference, 61(2019)

10. A.V. Tkachev, O. L. Tkachev, V.I. Rossokha, Agricultural biology, 2, 302(2018)

11. A.V. Tkachev, Molecular and Applied Genetics, 19, 79(2015)

12. A.V. Tkachev, O. L. Tkacheva, M.R. Shvetsova, N.V. Yavnikov, I.A. Koschaev, Modern molecular genetic research methods in physiology, zoohygiene, veterinary medicine and biological safety: monograph (Belgorod: Publishing house of the Belgorod GAU named after V.Ya. Gorin), 414 (2020) 
13. V.I. Tyschenko, V.P. Terletskiy, Modern scientific research and innovations, 8(64), 158(2016)

14. A.M. Kovalenko, A.V. Tkachev, O.L. Tkacheva, B.V. Gutyj, O.I. Prystupa, M.D. Kukhtyn, V.R. Dutka, Ye.M. Veres, O.O. Dashkovskyy, V.V. Senechyn, M.B. Riy, V.A. Kotelevych, Ukrainian Journal of Ecology, 10(1), 300 (2020) 